\title{
21
}

\section{School Belonging: The Importance of Student and Teacher Relationships}

\author{
Kelly-Ann Allen, Christopher D. Slaten, Gökmen Arslan, \\ Sue Roffey, Heather Craig, and Dianne A. Vella-Brodrick
}

School belonging is a multidimensional construct encompassing emotional and behavioural components (e.g., respected, accepted, and included; Arslan \& Duru, 2017; Goodenow \& Grady, 1993; Haugen, Morris, \& Wester, 2019; Karcher \& Lee, 2002). A student's sense of belonging to school has attracted growing attention from researchers and practitioners in recent years due to its ability to predict a wide variety of educational and developmental outcomes (Allen \& Bowles, 2012; Arslan, 2018; Arslan \& Duru, 2017;

K.-A. Allen ( $\otimes)$

The Faculty of Education, Monash University, Melbourne, VIC, Australia e-mail: kelly-ann.allen@unimelb.edu.au

C. D. Slaten

College of Education, University of Missouri, Columbia, MO, USA

G. Arslan

Faculty of Education, Mehmet Akif Ersoy University, Burdur, Turkey

S. Roffey

University of Exeter, Exeter, UK

H. Craig

The School of Public Health and Preventive Medicine, Monash University, Melbourne, VIC, Australia

D. A. Vella-Brodrick

Centre for Wellbeing Science, Melbourne Graduate School of Education, The University of Melbourne, Melbourne, VIC, Australia 
Osterman, 2000). School belonging also positively contributes to a number of factors that promote student academic functioning, mental health, and wellbeing (Allen, Kern, Vella-Brodrick, Hattie, \& Waters, 2018; Allen \& Bowles, 2012; Arslan, 2021; Arslan, Allen, \& Ryan, 2020). However, even though scholars and educators are aware of the impact of school belonging on student outcomes, the research on classroom interventions and school environment is relatively sparse. Currently, there are very few strategies and interventions available to schools that specifically target school belonging.

Substantial research has indicated that the student-teacher relationship provides a powerful avenue for schools concerned with increasing perceptions of school belonging among their students (cf. Allen, Kern, Vella-Brodrick, Hattie, \& Waters, 2018). However, creating strong student-teacher relationships is not without its challenges. Teachers may feel pressured by schedules, constrained by various responsibilities associated with their positions, and inhibited by systemic issues. Nevertheless, we suggest that building relationships within a school provides an attainable, cost-effective, and readily available strategy for building a culture of school belonging.

In this chapter, we first highlight the importance of relationships, and then focus specifically on school belonging. We highlight how school belonging can be assessed, and the limited interventions to support school belonging. We identify the importance of teachers in supporting a sense of belonging, and present some of the challenges associated with student-teacher relationships. We point to the role that school leaders can play in supporting belonging within the school. We then consider belonging and relationships in the context of higher education, suggesting that building strong relationships with teachers for students at both schools and universities should be a core consideration in positive education. Finally, we highlight potential future directions.

\section{Relationships Matter}

Relationships are integral to who we are as human beings. Studies and reviews repeatedly point to interpersonal relationships being a core human need (Allen, Kern, McInerney, Rozec, \& Slavich, 2021; Baumeister \& Leary, 1995; Ryan \& Deci, 2000). Some of the earliest studies in developmental psychology focused specifically on the role that relationships-particularly between a child and their primary caregiver, have on subsequent life experiences. The Internal Working Models of Attachment Relationships suggests that attachments during the formative years have a significant influence upon 
the quality of relationships later in life (Bowlby, 1958, 1969). Generally, a secure relationship is characterized by warmth, supportiveness, trust, involvement, and responsiveness, whereas insecure relationships are characterized by mistrust, fear, and avoidance (Bretherton \& Munholland, 1999). Poor attachment has a range of implications, including neurological, behavioural, psychological, and social effects, and results in an insecure sense of self and conflicting relationships. In contrast, it has now been well established that warm and responsive early connections result in a more optimistic outcome of good psycho-social functioning (Gerhardt, 2015). While early attachment research focused specifically on primary caregivers, subsequent studies have clearly found that extended family members and others in the community can promote a positive sense of self and make a significant difference in a young person's resilience and life trajectory (e.g., Goldstein, 2016). For instance, Obsuth et al. (2017) found that the relationship a student has with a teacher at 10 or 11 years of age influences attitudes and behaviour towards other adult relationships four years later.

For school-age children, good social relationships support social and emotional wellbeing (Allen, Vella-Brodrick, \& Waters, 2017; Australian Institute of Health and Welfare, 2007), and are important for helping students to succeed at school (Johnson, 2009). Roffey (2012) identified the power of positive relationships across many contexts, including schools, organizations, and families. Positive emotionally literate interactions have been found to be healing in challenging circumstances such as family breakdown (Dowling \& Elliott, 2012) and conflict (Edmund, 2012). Relationships also impact significantly on health and wellbeing outcomes (e.g., O'Connell, O'Shea, \& Gallagher, 2016; Warren \& Donaldson, 2018). As Huppert (2012) noted:

The foundation of what makes lives go well is not the individual but the quality of our relationships; the development of trust, the giving and receiving of love and support and the myriad ways in which relationships can be life-enhancing. (p. vii)

Indeed, Peterson (2006) summarized the essence of positive psychology as: "other people matter" (p. 249).

Importantly, the mere presence of positive social relationships is insufficient; the quality of those relationships, the context in which relationships occur, and the emotional experiences arising through interactions with others also matter (Allen, 2020; Baxter, Weston, \& Qu, 2011; Lim, Allen, Craig, Smith, \& Furlong, 2021). This quality aspect has been described in different ways over the past several decades. For example, in their Social Development Model, Hawkins and Weis (1985) suggested that it was the sense of 
being socially bonded with a student's family, school, peers, and community that influenced behaviour. The model suggests that opportunities to connect are necessary but insufficient for social bonds to form; the social bonding experience must also be positive. In other words, pro-social relationships will not singlehandedly develop a feeling of belonging. Social skills and positive experiences during one's interactions with others are also important elements (Allen, Boyle, Lachlan, \& Craig, 2020).

Similarly, guided by Self-Determination Theory (Ryan \& Deci, 2000), Zimmer-Gembeck, Chipuer, Hanisch, Creed, and McGregor (2006) suggested that it is the combination of positive relationships that support a sense of autonomy, relatedness, and competence, combined with positive environmental experiences that encourages students to be concerned about school and to be proactively involved with their academic pursuits. One important variable of this model is the way students feel about their teachers and peers. In particular, Zimmer-Gembeck et al. suggest that school belonging serves as a mediator between relationships and engagement at school. That is, when students feel that they have good relationships with their teachers and peers, they gain a sense of belonging, which results in greater school engagement. This engagement in learning, fuelled by a sense of school belonging, in turn has been linked to better academic performance and achievement (Dweck, 1999; Eccles \& Wigfield, 2002; Skinner, Zimmer-Gembeck, Connell, Eccles, \& Wellborn, 1998). Therefore, a model of school belonging should consider a student's relationships with his or her teachers and peers (Osterman, 2000) and the extent to which the relational quality creates an encouraging environment that fulfils the student's need for autonomy, competence, and belongingness (Zimmer-Gembeck et al., 2006).

\section{School Belonging}

Within this background on the importance of relationships in mind, we turn specifically to the primary context of relationships within school communities - captured through the concept of school belonging. The Organisation for Economic Cooperation and Development (OECD, 2019) reports that one in three students around the world do not feel a sense of belonging to their school, and these numbers are steadily rising (2019). Locally and internationally, this trend is a cause for concern. Students who lack a sense of belonging are more likely to engage in problematic behaviour, suffer from mental illness, and experience low achievement (Allen \& McKenzie, 2015; Abdollahi, Panahipour, Tafti, \& Allen, 2020; Anderman, 2002; Arslan \& 
Coşkun, 2020; Henrich, Brookmeyer, \& Shahar, 2005; Simons-Morton, Crump, Hayine, \& Saylor, 1999; Van Ryzin, Gravely, \& Roseth, 2009). The most at-risk students are the ones who are already vulnerable (Aerts, Van Houtte, Dewaele, Cox, \& Vincke, 2012; Gutman \& Midgley, 2000; Uwah, McMahon, \& Furlow, 2008), and these effects can continue into adult life (Hagerty, Williams, \& Oe, 2002). We begin with an illustration of not belonging, before unpacking what school belonging is and the important role that teachers play in supporting belonging.

\section{Dianne's Allergy Story}

Bringing the importance of school belonging and the power of studentteacher relationships to life, Fig. 21.1 provides a personal story experienced by one of the co-authors. This story illustrates how important quality relationships and a sense of belonging are and how a lack of these can lead an individual to behave in uncharacteristic ways such as being deceitful. Could there have been a different outcome if she had stronger relationships with her teachers? What if her teachers had truly known her as an individual in a way that they could detect the mild nuances of her visible affect and body language in the same way a good friend may detect an unhappy child even if they are wearing a smile on their face? What if Dianne was provided with a safe place and support from her teachers to express her feelings, rather than permission to stay away from school? Based on an extensive and growing literature, we can deduce that Dianne's school experience may have been improved through forming stronger school-based relationships and greater support to build her sense of belonging to school. We turn to that literature now.

\section{Defining School Belonging}

The terms used to describe school belonging vary considerably in the literature (e.g., Allen \& Bowles, 2012; Anderman, 2002; Knifsend \& Graham, 2012; Ma, 2003; Nichols, 2006; Slaten, Ferguson, Allen, Brodrick, \& Waters, 2016). The definition presented by Goodenow and Grady (1993, p. 60) remains the most frequently utilized: "the extent to which students feel personally accepted, respected, included, and supported by others in the school social environment". This notion has been supported in a wide range of work demonstrating that the central themes of school belonging are related to teacher supportiveness, the presence of good friends, engagement 


\begin{abstract}
It all started when I was transitioning from primary to high school. After a highly rewarding Year 6 at my primary school where I felt socially connected, academically capable, and sporty, I now felt isolated and alone at high school, especially as I was the only person from my primary school to attend this school. Every school morning and before each class, I would feel anxious about who I was going to sit next to. I felt like the teachers never really got to know me and the fact that I was shy and seldom said anything didn't seem to help. I felt invisible and worthless.

I was grateful for weekends and school holidays, as this meant I could spend time with my family in a warm and supportive environment. I spent most of my school holidays with my auntie who spoilt me with attention, outings, and treats and I cherished spending time with her. She was my saving grace. When the school term commenced again, I had trouble containing my sadness. I missed my auntie and I did not want to go to school. I was sitting in English class with uncontrollable tears streaming down my face. Despite efforts to wipe away my tears the teacher noticed and asked if I was alright. Totally embarrassed, I said "Yes, I'm not sure why my eyes are watering up". The teacher moved on but after a few minutes noticed that my tears had not subsided. She brought me a box of tissues which I used to wipe away my tears. This aggravated the skin around my eyes which became red and puffy. Again, the teacher asked if I was alright. to which I responded, "I'm not sure why my eyes are so watery". She asked if I had any allergies and I said I didn't know. She advised me to go home to see if my condition would settle down.

My mum was contacted, and I was sent home for the day. Everyone was concerned about the redness around my eyes. The next day I was sent to school again, but the experience of being back at school and feeling completely isolated seemed unbearable and the tears returned. Because I didn't admit there was a problem, the tears were interpreted by school staff to be a physical condition, an allergic response to some of the bushes in the school yard. I was sent home again. No one really asked me any specific questions about what was troubling me, so I just went along with it. I was too embarrassed to express how I was feeling, and I was enjoying the newfound attention and the absence from school. Once my sadness and crying settled, and my eyes were no longer red I realised I would have to go back to school. I decided to use makeup, rouge, to make the skin around my eyes look irritated. This worked well. I stayed home from school for over a week. I ended up going to the doctor, who after examining me (with makeup around my eyes) recommended I get a full allergy test at the hospital. My concerned parents immediately organized for me to have this test at the hospital. I turned up with rouge around my eyes, was pricked numerous times on my hands to test for allergic reactions and all this time, teachers, parents and medical staff did not suspect a thing. Unsurprisingly no allergies were detected. Nearly three months later with the help of make-up, I had not attended school except for a oneweek trial at the local technical school which did not go well. This took me to the end of the year where I then stopped applying make-up to the skin around my eyes and instead enjoyed the Summer holidays with my family.
\end{abstract}

Fig. 21.1 Dianne's allergy story: An illustration of the challenge of fostering school belonging and the power of student-teacher relationships 
in academic progress, and fair and effective discipline (Centers for Disease Control and Prevention, 2009; Libbey, 2004; Wingspread Declaration on School Connections, 2004). Despite a lack of consistency in definitions of school belonging and a variety in the terms used to describe belonging, researchers have generally focused on three key components of this construct: school-based experiences and relationships, student-teacher relationships, and student general feelings about school as a whole (Allen \& O'Brien, 2013; Allen et al., 2018).

Interestingly, several definitions of school belonging implicitly include teacher support. For example, Blum and Libbey (2004) noted that school belonging involves students believing that the adults involved at their school care about their learning, are interested in them as individuals, and maintain high academic expectations of them. The literature also points to school belonging necessitating positive teacher-student relationships and a feeling of safety at school (Anderman, 2002; Jose, Ryan, \& Pryor, 2012; Rowe \& Stewart, 2009).

\section{Measurement}

The measurement of school belonging is a critical step to understand and develop prevention strategies in fostering student healthy development and wellbeing. Several measurement tools have been developed (Allen \& Kern, 2017; Arslan \& Duru, 2017). For example, the Psychological Sense of School Membership (PSSM; Goodenow, 1993) is one of the most widely used measures for assessing the sense of belonging among children and adolescents (Goodenow, 1993). The PSSM measures student feelings of belonging, or psychological membership, within the school environment and has been applied in various academic and cultural contexts (e.g., Anderman, 2003; Cheung \& Hui, 2003; Shochet, Dadds, Ham, \& Montague, 2006). The School Belongingness Scale (SBS) assesses the school belonging of children and adolescents (Arslan \& Duru, 2017). The SBS has sound psychometric properties, and includes two components: school inclusion and school exclusion. School inclusion refers to social acceptance within the school environment while school exclusion refers to social rejection. Slaten and colleagues (2018) developed a youth belonging measure that captures several salient domains in a youth's life: family, school, and peer belonging. This 9item measure includes 3-items for each subscale and a total scale score, this abbreviated measure is seen as an efficient tool and utilized by scholars in multiple disciplines. In addition to these measures, there are many smaller sets of questions that have been used to assess school belonging (Allen \& Kern, 
2017). However, measures have been criticized for being too brief to assess the complexity and multiple features of school belonging (Allen \& Kern, 2017; Fredricks, Blumenfeld, \& Paris, 2004). Given the limited number of scales used to measure school belonging, there is a need to further identify the best way to capture school belonging.

Regardless of what the measure of school belonging should be, it is clear across the literature that the student-teacher relationship is a critical component. As described in more detail below, the student-teacher relationship provides a powerful resource in both assessing and promoting students' sense of school belonging (Allen et al., 2016, 2018; Arslan, 2020; Arslan \& Duru, 2017; Osterman, 2000; Uslu \& Gizir, 2017). As such, most measures of school belonging have emphasized the importance of good quality studentteacher bonds (Allen et al., 2016; Connell \& Wellborn, 1991). For example, Goodenow and Grady (1993) include "students' subjective feelings of being accepted, included, respected, and supported by others, especially teachers and friends, in the school social environment" (p. 66), asking for instance "the teachers here respect me". Similarly, the School Connectedness Scale (SCS) for adolescents includes questions such as "My teachers give me extra help when I need it" (Lohmeier \& Lee, 2011). Arslan and Duru (2017) include questions such as "I have close/sincere relationships with my teachers and friends". Clearly, measures of school belonging see the student-teacher relationship as an important resource in measuring and understanding of students' sense of belonging in school.

\section{Teacher Support}

In a large-scale synthesis of research, Hattie (2009) found a strong $(d=0.52)$ effect for the teacher-student relationship in enhancing academic outcomes in students. Similarly, through a meta-analysis of school belonging, which included 51 studies and 67,378 students Allen et al. (2018) found a large $(r=0.46)$ effect between teacher support and school belonging. Numerous other researchers have widely supported the importance of the teacherstudent relationship for numerous academic and psychosocial outcomes (e.g., Korpershoek, Harms, de Boer, van Kuijk, \& Doolaard, 2016).

Numerous studies find that teacher relationships positively influence young people's feelings about their schools, and that the role of a teacher extends beyond providing opportunities for improved academic outcome (e.g., Cemalcilar, 2010; Hallinan, 2008; Klem \& Connell, 2004). For instance, Klem and Connell (2004) noted: "students who perceive teachers as 
creating a caring, well-structured learning environment in which expectations are fair are more likely to report engagement in school" (p. 270). In a sample of 3,238 students from Hong Kong, students were more likely to have high expectations about their educational experiences if they had positive relationships with their teachers and felt like they belonged at school (Wong, Parent, \& Konishi, 2019). Similarly, Wallace, Ye, and Chhuton, (2012) showed that support, fairness, and lack of conflict with teachers predicted a sense of belonging in adolescence. Further, students' perceptions about the relationship with their teacher were found to be contextual and influenced by how effective the teacher was at ensuring the pedagogy and content resonated with the students and whether the students thought their teacher cared for them.

Across studies, good relationships arise when students feel cared for, accepted, and respected by their teachers. For example, in a longitudinal study of 714 elementary school students who were academically at risk, Hughes (2011) found that children were more likely to see themselves as academically capable and had a sense of school belonging when students perceived their teacher as being warm and accepting and had a sense of social support that reflected care, respect, and cooperation. Crouch, Keys, and McMahon (2014) found that teachers fulfilled an important social function for students if they respected and valued students, offered social support, and developed a good rapport while teaching the curriculum. Anderman (2002) found that students reported greater belonging when they perceived their teachers provided mutual respect in the classroom. Moreover, pointing to the school as a community, rather than the sole responsibility of a single teacher, Roffey (2012) found that students reported a greater belonging when staff members generally (not necessarily the students' teachers) were perceived as being available to students, showed that they cared about them, and positively interacted with them.

While social support is important as this addresses students' need for relatedness and care, academic support also matters, as this supports their need for competence. For instance, across 434 twelve-year-old students, students achieved more and felt a greater sense of school belonging when their teachers used a mastery goal orientation involving assisting students to acquire new skills and master new situations through the development of personal goals, combined with academic pressure (Stevens, Hamman, \& Olivárez, 2007). These teachers were more likely to challenge students, encourage their ideas, and ask them to explain their work. The pressure was for students to go beyond their comfort zones and engage in their learnings. 
And the more that teachers promoted learning over performance, the more school belonging students felt.

It is clear that the student-teacher relationship matters. Research has demonstrated that the relationship remains important as a young person progresses through secondary school (Longobardi, Prino, Marengo, \& Settanni, 2016). Of course, other relationships, including those with parents and peers, also impact upon a students' sense of belonging (Allen et al., 2018; Quinn \& Oldmeadow, 2013; Tillery, Varjas, Roach, Kuperminc, \& Meyers, 2013), and other adult connections may become more important as a student progresses through secondary school. However, the support provided by teachers may fulfil a specific set of needs, such as autonomy and competence. Perhaps the best teachers are not simply imparters of knowledge on a particular subject nor counsellors providing social and emotional care, but educators caring about the holistic development of their students.

\section{The Current Context}

It is clear that the student-teacher relationship matters for cultivating a sense of school belonging, good psychosocial functioning, and academic outcomes. Yet OECD (2019) data have revealed some disturbing statistics about student perceptions of relationships with their teachers. A significant portion of students believed their teachers gave them the impression they were less intelligent than they were, their teachers disciplined them more harshly than others, or their teachers ridiculed or insulted them in front of others. Clearly, many students do not feel their relationships with their teachers are supportive.

There are signs of inequity in terms of who is at risk for poor outcomes, with the vulnerable and disadvantaged at higher risk. For instance, while international data suggest that a sense of belonging for Australian students has declined across students (OECD, 2019), De Bortoli (2018) found that several groups were less likely to feel like they belong including indigenous students, those with disability, and those from the LGBT community. Students in remote communities also reported feeling more like an outsider than those in metropolitan areas. It is clear that there needs to be more effort made to include those who are at risk. Although it is now widely recognized that school belonging is relevant to engagement, academic outcomes, and mental health, there continue to be difficulties at the local and national levels in implementing strategies that promote positive teacher-student relationships . 
For example, since 2010 in the U.K., state education has increasingly focused on academic subjects at the expense of creative subjects and humanities. This has been coupled with expectations on teachers to account for everything they and students do in the classroom. Schools are inspected by the Office for Standards in Education, who rate them from inadequate to outstanding. This rating includes the results of tests that students take at the end of years 2, 6, and 9. This approach to education has led to several unwanted consequences. Firstly, a teacher's time is consumed with paperwork and getting through the demands of the curriculum that there is little time to establish and maintain relationships. The priority for teachers, especially in the secondary sector, is on delivering their subject, rather than responding to the needs of the young people who they are teaching and taking account of their individual contexts. While this may have little consequence for students from strong, supportive families, for young people where school is their primary source of consistency, security, and welcome, this can leave them marginalized, resulting in further disadvantage. The grading system also sets schools up in competition with each other. Senior managers and school governors may put pressure on teachers to ensure the school gets an "outstanding" rating. Students feel pressure to meet the high academic standards, and place pressure on teachers to help them meet those standards. Behaviour also deteriorates where students no longer feel they matter and school becomes an irrelevance. Rather than trying to promote a sense of inclusive belonging, many schools have resorted to exclusion and "off-rolling", a practice where parents are persuaded to remove their child from the school so that these children do not bring down the school's exam average.

While this illustrates the experiences of one country, similar practices and pressures are occurring worldwide (e.g., Hirschfield, 2008; Sargeant, 2016) teachers are leaving the profession in significant numbers. In 2018, nearly $10 \%$ of teachers in the U.K. left the profession, with slightly more in the secondary sector. The retention rate of newly qualified teachers has fallen considerably since 2011 (National Foundation for Educational Research [NFER], 2019). There are increasing concerns about young people's mental health, school violence, and gang-related activity indicating that more conversations and actions need to occur in this space.

\section{Interventions to Support Belonging}

Although this paints a rather depressing picture, many teachers and schools are doing their best to support students, often under challenging circumstances. There are signs that different approaches are gaining traction. In 
the wake of burgeoning systemic pressures on the teaching profession, interventions for relationship building with students that can be immersed into day-to-day school life and embedded in existing practices are beneficial (Allen \& Kern, 2019).

Very few empirically tested interventions are available that specifically address school belonging through the student-teacher relationship. This may be because the student-teacher relationship is expected to occur naturally. Still, in a school climate of competing interests, teacher stress, and job dissatisfaction, even seemingly obvious interventions have a need and place for increasing school belonging. Cook et al. (2018) found that something as simple as a personal greeting can have merit: a teacher who greets students at the door can increase student engagement by $20 \%$.

Another seemingly simple intervention devised by Gehlbach et al. (2016) allowed for teachers and students to know each other better based on the assumption that when people perceive themselves as similar, greater liking, and closer relationships result. Students in the treatment condition received feedback on five similarities that they shared with their teachers; each teacher received parallel feedback regarding similarities. The study found improved relationships and higher course grades for students and teachers who shared similarities. This brief intervention appeared to close the achievement gap at this school by over $60 \%$. Vidourek and King (2014) similarly found that those who felt positively connected to their students felt significantly more likely than their counterparts to use school connectedness strategies and felt significantly more confident than teachers who reported low use of strategies to connect students to school.

Cornelius-White (2007) found that positive student outcomes were associated with learner-centred teacher practices, which honour student voices, promote higher-order thinking, align teaching with individual needs, and adapt instructions that have been associated with positive student outcomes. Researchers have found that these teaching practices increase mastery and performance goals in adolescents, and promote motivation and academic engagement (Meece, 2003; Meece, Herman, \& McCombs, 2003). Shanghai, Akgul, Cokamay, and Demir (2016) found that students perceived their teachers as being more supportive if the teachers were aware of the specific characteristics of individual students. Supportive teachers considered different learning levels and kept students' views in mind when conducting activities in the classroom and assigning homework.

Having social and emotional learning (SEL) programs that give students agency for the emotional climate of their class and mix everyone up to discuss issues (not incidents) is another way of promoting connectedness 
(Dobia, Parada, Roffey, \& Smith, 2019). SEL can also provide opportunities for teachers to get to know their students in informal activities and to develop their understanding of what promotes or inhibits their engagement with others. This is especially critical in the secondary sector where school belonging is most likely to decline.

Bringing many of the different strategies and interventions together, Megan Pedlar (2018) suggested the following strategies for building studentteacher relationships :

- Prioritize high-quality teacher-student relationships

- Create a supportive and caring learning environment

- Offer emotional support to students

- Be sensitive to students' needs and emotions

- Show interest in students

- Try to understand students' point of view

- Be respectful and provide fair treatment

- Foster positive peer relationships and mutual respect among classmates to establish a sense of community

- Engage in positive classroom management

While many of the features within Pedlar's list may be intuitively provided by teachers and school leaders, there is room within this body of work for more rigorous empirical evidence. Research on student-teacher relationships appear paramount to school belonging and require future research to reveal the precise mechanisms for increasing school belonging. In addition, an important area for further study involves strategizing ways schools can foster teacher support and helping schools specifically pay attention to cultivating teacher-student relationships, despite the broader cultural pressures that might exist.

\section{The Role of School Leadership}

Although individual teachers can do a lot to support a sense of belonging with the young people they interact with on a regular basis, this will not be sustainable unless it is prioritized across the whole school. The vision, direction, and priorities of the school generally are set by a senior leadership team, such that the role of school leaders is central (Roffey, 2007). If leaders are passionate that each child has the opportunity to do as well as they can in all 
dimensions of their development, then the leaders are more likely to emphasize and support an inclusive sense of belonging across the school community (Roffey, 2007). In contrast, when school leaders singularly focus on "academic success", then students who do not "fit" are more at risk (Dulfer, Polesel, \& Rice, 2012). Further, many people find themselves in leadership roles with little training or support for how to lead well and manage the many demands, stakeholder voices, and priorities of the community. Without a clear vision for the school, the priorities of the broader education system tend to take priority, leaving behind the social and emotional needs of the community.

Effective school leaders have the intellectual capacity and relevant knowledge set for their roles, as well as necessary emotional knowledge and skills (Scott, 2003). Studies (e.g., Ma, 2003; O'Keeffe, 2013) point to several practices that effective leaders engage in that support belonging:

- They appreciate that some children will only achieve when the learning environment is safe and supportive, and work hard to create a school environment that is both physically and psychologically safe.

- They ensure that there is time and/or flexibility in the school day for teachers to establish positive relationships with their students.

- They organize professional development so that staff know the importance of this and how to do it.

- They support a behaviour policy that is relational rather than based in reward and punishment and they will be aware of some of the issues that may undermine connectedness, such as an inflexible focus on uniform infringements.

- They encourage teachers to provide pastoral support to students.

- They ensure that time is allocated to get to know and understand their students and show that this is a valued part of their role in the school.

School leaders have both the opportunity and the responsibility to create an environment that can enable wellbeing in those they lead. Considering the importance of belonging for so many desired outcomes (Allen et al., 2018), we suggest that it is crucial that creating environments of belonging are prioritized.

\section{Relationships and Belonging in Higher Education}

Most of the research on belonging has focused on the primary and secondary levels, with limited focus within higher education . Existing studies and 
theoretical models consistently include belonging as an integral construct in understanding university student retention and academic performance (e.g., Strayhorn, 2018; Tinto, 1987). For instance, the widely accepted Tinto Model of College Student Retention points to the importance of students feeling a sense of belonging on campus and being able to relate to other students on campus as well as university personnel, including faculty and staff. Similarly, emphasizing students on the margin, Strayhorn (2018) posits that student social context and feeling unsupported or unwelcome may contribute to a more heightened level of importance to feeling a sense of belonging on campus.

\section{Assessing Belonging Within Higher Education}

One reason that there has been limited empirical research on belongingness in higher education is the lack of sound measurement of the construct. In the few studies where belongingness has been examined, higher education scholars have largely adapted K-12 school belonging scales, such as the PSSM (Goodenow, 1993). But students in higher education environments have vastly different experiences compared to K-12 schools. The higher education experience often involves living at or near the educational institution, engaging in activities and group activities outside of the classroom, living with peers, and taking courses in a variety of different disciplines in different buildings. These are just a few of the many differences in the educational environment when transitioning to higher education.

Notably, Slaten and colleagues (2018) created a belongingness measure to be utilized specifically in higher education settings. Through qualitative research, consulting experts in the field, and performing an exploratory factor analysis (EFA) on an initial item list, they identified and confirmed a three factor structure that encompasses belonging in higher education: university/school affiliation (pride in being part of the university), university/school support (feeling accepted, valued, and supported by the university), and faculty/staff relations (feeling psychologically safe and comfortable in interacting with faculty and staff). A valid and reliable measure of belonging that is specific to the higher education environment can help aid university personnel and higher education scholars in more accurately understanding the impact belonging may have on college student outcomes, as well as serve as a starting point to designing interventions that could enhance belonging on campus. 


\section{Impact of and Approaches to Belonging in Higher Education}

Existing studies on belonging in higher education identify promising areas of intervention and support. University students with a higher sense of belonging are more engaged in the classroom and generally have more successful academic outcomes (Hausmann, Ye, Schofield, \& Woods, 2009; Wang \& Eccles, 2012), and a sense of belonging has been linked to positive psychosocial and behavioural outcomes (Hurtado \& Carter, 1997; Osterman, 2000; Pittman \& Richmond, 2007). Recently, Gillen-O’Neel (2019) examined the relationship between belonging on campus and student engagement for both first-generation collegess students and continuing-generation college students. The results suggest that, with few exceptions, belonging was associated with all types of student engagement. Further, for first-generation students, the concept of belonging appeared to be more powerful, confirming Strayhorns' (2018) theoretical assertions that for those students experiencing a more difficult time on campus, sense of belonging is even more important.

Relationships with faculty members may be particularly important for cultivating a sense of belonging at the university. For instance, Slaten et al. (2018) examined the potential factors that make up belonging in higher education settings, finding that one of these salient factors was the importance of students having positive relationships with faculty. Walton and Cohen $(2007,2011)$ designed an intervention for college students that focused on statements related to social difficulties in college and problemsolving solutions to these concerns. Results suggested that the intervention successfully increased students sense of belonging and their academic performance . Upon examining the impact of instructional adjustments, Gilken and Johnson (2019) found that classrooms that engaged in peer review and feedback from their classmates felt a greater sense of belonging by the end of the semester, suggesting that faculty should provide opportunities for students to connect with one another in the classroom. Perhaps the most promising intervention research has been conducted by Patterson Silver Wolf and colleagues (2019), who examined a brief intervention curriculum for community college students, specifically focused on underrepresented minorities and mattering in higher education settings. The results of multiple randomized control trials found that the intervention improved both students' sense of belonging and retention. Additional studies focusing on best approaches for prioritising and cultivating a sense of belonging and good student-professor relationship at the higher education level will be an important area to focus on in the coming years. 


\section{Future Directions}

We end with consideration of some of the future directions for belonging research. Many researchers have studied school belonging and teacher support by investigating bivariate relationships. For example, most studies reported a correlation between two variables (e.g., belonging and teacher support), which can establish relational inferences, but say little about causation (Thompson, Diamond, McWilliam, Snyder, \& Snyder, 2005). While this has provided a homogenous understanding of concepts related to school belonging, this offers little information about what schools can do to increase belonging in their unique environments. Considering the dynamic nature of social relationships, simple causation most likely does not occur, but greater understanding of specific strategies and actions teachers and others in the school community can take to increase a sense of belonging is needed.

Due to the tendency to focus on student perspectives about belonging, the voices of school leaders and teachers are often absent from this research (Shochet, Smyth, \& Homel, 2007; Uwah et al., 2008). Likely, teachers and other staff who feel a greater sense of school belonging are more committed to the school and perhaps better educators, but how a sense of belonging plays out for adults in the school community, and the impact of that on students is unknown.

While studies find that the student-teacher relationship is instrumental to belonging, less is known about how to improve those relationships, as are the most effective types of supports that teachers can offer and the interplay between the variables that comprise teacher support. Future work might empirically consider characteristics of good student-teacher relationships and consider specific strategies for improving relationships, across different school contexts.

\section{Conclusion}

In what has been called a "loneliness epidemic", the past decade has brought an alarming rise in loneliness for people worldwide, with adolescents and senior citizens particularly at risk (Australian Psychological Society, 2018). Schools are essentially micro-societies that represent our broader societies. As such, if we can learn how to build a sense of belonging within our schools, perhaps these lessons can be applied across other communities, including assisted living facilities and nursing homes. Further, if young people develop the skills and capabilities to connect well with others, perhaps we 
can cultivate a more connected community within a currently disconnected world.

Within schools, there are some barriers to the connections that adults have with students, such as the organizational structure of schools, teacher instructional practices, the transitions that are a part of schooling, and discipline policies. Adults play a role in promoting student growth and development, such as through addressing the social conditions within a school. Students need the opportunity to feel accepted, cared for, and affirmed in their school. There is no greater way to achieve this then by utilizing the school personnel that they are around the most: teachers.

\section{References}

Aerts, S., Van Houtte, M., Dewaele, A., Cox, N., \& Vincke, J. (2012). Sense of belonging in secondary schools: A survey of LGB and heterosexual students in Flanders. Journal of Homosexuality, 59(1), 90-113.

Abdollahi, A., Panahipour, S., Tafti, M. A., \& Allen, K. A. (2020). Academic hardiness as a mediator for the relationship between school belonging and academic stress. Psychology in the Schools. https://doi.org/10.1002/pits.22339.

Akgul, G., Cokamay, G., \& Demir, E. (2016). Predictors of teacher support: Turkey and Shanghai in the Programme for International Student Assessment, 2012. Eurasian Journal of Educational Research, 63, 115-132.

Allen, K. A. (2020). The psychology of belonging. Routledge (Taylor and Francis Group).

Allen, K. A., \& Bowles, T. (2012). Belonging as a guiding principle in the education of adolescents. Australian Journal of Educational \& Developmental Psychology, 12, $108-119$.

Allen, K. A., Boyle, C., Lachlan, F., \& Craig, H. (2020). How multi-systemic social skills training can pave the way for inclusive practices for students with autism spectrum disorders in mainstream schools. In C. Boyle, S. Mavropoulou, J. Anderson, \& A. Page (Eds.), Inclusive Education: Global Issues \& Controversies. Brill.

Allen, K. A., \& Kern, M. L. (2017). School belonging in adolescents: Theory, research and practice. Springer Social Sciences.

Allen, K. A., Kern, M. L., Vella-Brodrick, D., Hattie, J., \& Waters, L. (2018). What schools need to know about fostering school belonging: A meta-Analysis. Educational Psychology Review, 30(1), 1-34. https://doi.org/10.1007/s10648016-9389-8.

Allen, K. A., \& Kern, P. (2019). Boosting School Belonging in Adolescents: Interventions for teachers and mental health professionals. Abingdon, UK: Routledge. 
Allen, K. A., Kern, M., McInerney, D., Rozec, C., \& Slavich, G. (2021). Belonging: A Review of Conceptual Issues, an Integrative Framework, and Directions for Future Research. Australian Journal of Psychology. https://doi.org/10.1080/000 49530.2021.1883409.

Allen, K. A., \& McKenzie, V. (2015). Adolescent Mental Health in an Australian Context and Future Interventions. International Journal of Mental Health, 44, 80-93. https://doi.org/10.1080/00207411.2015.

Allen, K. A., Vella-Brodrick, D., \& Waters, L. (2016). Fostering school belonging in secondary schools using a socio-ecological framework. The Educational and Developmental Psychologist, 33(1), 97-121.

Allen, K. A., Vella-Brodrick, D., \& Waters, L. (2017). School belonging and the role of social and emotional competencies in fostering an adolescent's sense of connectedness to their school. In E. Frydenberg, A. J. Martin, \& R. J. Collie (Eds.), Social and Emotional Learning in Australia and the Asia-Pacific: Perspectives, Programs and Approaches (1st ed., pp. 83-99). Singapore, Singapore: Springer. https://doi.org/10.1007/978-981-10-3394-0_5.

Anderman, E. M. (2002). School effects on psychological outcomes during adolescence. Journal of Educational Psychology, 94(4), 795-809.

Anderman, L. H. (2003). Academic and social perceptions as predictors of change in middle school students' sense of school belonging. Journal of Experimental Education, 72(1), 5-22.

Arslan, G. (2018). Exploring the association between school belonging and emotional health among adolescents. International Journal of Educational Psychology, 7(1), 21-41. https://doi.org/10.17583/ijep.2018.3117.

Arslan, G. (2020). Loneliness, college belongingness, subjective vitality, and psychological adjustment during coronavirus pandemic: Development of the College Belongingness Questionnaire. Journal of Positive School Psychology. Retrieved from https://journalppw.com/index.php/JPPW/article/view/240.

Arslan, G. (2021). School bullying and youth internalizing and externalizing behaviors: Do school belonging and school achievement matter? International Journal of Mental Health and Addiction. https://doi.org/10.1007/s11469-021-00526-x.

Arslan, G., Allen, K., \& Ryan, T. (2020). Exploring the Impacts of School Belonging on Youth Wellbeing and Mental Health: A Longitudinal Study. Child Indicators Research. https://doi.org/10.1007/s12187-020-09721-z.

Arslan, G., \& Coşkun, M. (2020). Student subjective wellbeing, school functioning, and psychological adjustment in high school adolescents: A latent variable analysis. Journal of Positive School Psychology, 4(2), 153-164. https://doi.org/10. 47602/jpsp.v4i2.231.

Arslan, G., \& Duru, E. (2017). Initial development and validation of the School Belongingness Scale. Child Indicators Research, 10(4), 1043-1058.

Australian Institute of Health and Welfare. (2007). Australia's welfare 2007 (Cat. no. AUS 93). Author. 
Australian Psychological Society. (2018). Australian loneliness report. APS. https:// psychweek.org.au/wp/wp-content/uploads/2018/11/Psychology-Week-2018-Aus tralian-Loneliness-Report-1.pdf.

Baumeister, R. F., \& Leary, M. R. (1995). The need to belong: Desire for interpersonal attachments as a fundamental human motivation. Psychological Bulletin, 11(3), 497-529.

Baxter, J., Weston, R., \& Qu, L. (2011). Family structure, co-parental relationship quality, post-separation paternal involvement and children's emotional wellbeing. Journal of Family Studies, 17(2), 86-109.

Blum, R. W., \& Libbey, H. P. (2004). Executive summary. Journal of School Health, $74(7), 231-232$.

Bowlby, J. (1958). The nature of the child's tie to his mother. International Journal of Psycho-Analysis, 39, 350-373.

Bowlby, J. (1969). Attachment and loss: Volume 1. Basic Books.

Bretherton, I., \& Munholland, K. A. (1999). Internal working models in attachment relationships: A construct revisited. In J. Cassidy \& P. R. Shaver (Eds.), Handbook of attachment: Theory, research, and clinical applications (pp. 89-111). The Guilford Press.

Cemalcilar, Z. (2010). Schools as socialization contexts: Understanding the impact of school climate factors on students' sense of school belonging. Applied Psychology: An International Review, 59(2), 243-272.

Centers for Disease Control and Prevention. (2009). School connectedness: Strategies for increasing protective factors among youth. U.S. Department of Health and Human Services.

Cheung, H. Y., \& Hui, S. K. F. (2003). Mainland immigrant and Hong Kong local students' psychological sense of school membership. Asia Pacific Education Review, 4(1), 67-74.

Connell, J. P., \& Wellborn, J. G. (1991). Competence, autonomy and relatedness: A motivational analysis of self-system processes. In M. R. Gunnar \& L. A. Sroufe (Eds.), Minnesota symposium on child psychology, 22 (pp. 43-77). L. Erlbaum Associates.

Cook, C. R., Fiat, A., Larson, M., Daikos, C., Slemrod, T., Holland, E. A., et al. (2018). Positive greetings at the door: Evaluation of a low-cost, high-yield proactive classroom management strategy. Journal of Positive Behavior Interventions, 20(3), 149-159.

Cornelius-White, J. H. D. (2007). Learner-centered teacher-student relationships are effective: A meta-analysis. Review of Educational Research, 77, 113-143.

Crouch, R., Keys, C. B., \& McMahon, S. D. (2014). Student-teacher relationships matter for school inclusion: School belonging, disability, and school transitions. Journal of Prevention \& Intervention in the Community, 42(1), 20-30. https://doi. org/10.1080/10852352.2014.855054.

De Bortoli, L. (2018). PISA Australia in Focus Number 1: Sense of belonging at school. ACEResearch. https://research.acer.edu.au/ozpisa/30/. 
Dobia, B., Parada, R., Roffey, S., \& Smith, M. (2019). Social and emotional learning: From individual skills to group cohesion. Educational and Child Psychology, 36 (2), 79-90.

Dowling, E, \& Elliott, D. (2012). Promoting positive outcomes for children experiencing change in family relationships. In S. Roffey (Ed.), Positive Relationships: Evidence Based Practice across the World (pp.109-126). Springer.

Dulfer, N., Polesel, J. \& Rice, S. (2012). The Experience of Education: The Impact of High Stakes Testing on Students and their Families. Whitlam Institute, University of Western Sydney.

Dweck, C. S. (1999). Self-theories: Their role in motivation, personality and development. Psychology Press.

Eccles, J. S., \& Wigfield, A. (2002). Motivational beliefs, values, and goals. Annual Review of Psychology, 53, 109-132.

Edmund, L. (2012). Conflict and confrontation. In S. Roffey (Ed.), Positive Relationships: Evidence Based Practice Across the World (pp. 261-276). Springer.

Fredricks, J. A., Blumenfeld, P. C., \& Paris, A. H. (2004). School engagement: Potential of the concept, state of the evidence. Review of Educational Research, 74(1), 59-109.

Gerhardt, S. (2015). Why love matters: How affection shapes a baby's brain (2nd ed). Routledge.

Gilken, J., \& Johnson, H. L. (2019). Supporting belongingness through instructional interventions in community college classrooms. Community College Enterprise, 25(1), 32-50.

Gillen-O'Neel, C. (2019). Sense of Belonging and Student Engagement: A Daily Study of First- and Continuing-Generation College Students. Research in Higher Education, 62, 45-71. https://doi.org/10.1007/s11162-019-09570-y.

Goldstein, H., (2016). The relationship between grandparents and the caring, resilience, and emotional intelligence of grandchildren. ETD Collection for Pace University. AAI10182953. https://digitalcommons.pace.edu/dissertations/AAI10182953.

Goodenow, C. (1993). The psychological sense of school membership among adolescents: Scale development and educational correlates. Psychology in the Schools, 30(1), 79-90.

Goodenow, C., \& Grady, K. E. (1993). The relationship of school belonging and friends' values to academic motivation among urban adolescent students. The Journal of Experimental Education, 62(1), 60-71. https://doi.org/10.1080/002 20973.1993.9943831.

Gutman, L. M., \& Midgley, C. (2000). The role of protective factors in supporting the academic achievement of poor African American students during the middle school transition. Journal of Youth and Adolescence, 29(2), 223-249.

Hagerty, B. M., Williams, R. A., \& Oe, H. (2002). Childhood antecedents of adult sense of belonging. Journal of Clinical Psychology, 58(7), 793-801.

Hallinan, M. T. (2008). Teacher influences on students' attachment to school. Sociology of Education, 81(3), 271-283. 
Hattie, J. (2009). Visible learning: A synthesis of meta-analyses relating to achievement. Routledge.

Haugen, J., S., Morris, C., W., \& Wester, K. (2019). The need to belong: An exploration of belonging among urban middle school students. Journal of Child and Adolescent Counseling 5(1), 1-17. https://doi.org/10.1080/23727810.2018. 1556988.

Hausmann, L. R., Ye, F., Schofield, J. W., \& Woods, R. L. (2009). Sense of belonging and persistence in White and African American first-year students. Research in Higher Education, 50(7), 649-669.

Hawkins, J. D., \& Weis, J. G. (1985). The social development model: An integrated approach to delinquency prevention. Journal of Primary Prevention, 6 (2), 73-97.

Henrich, C. C., Brookmeyer, K. A., \& Shahar, G. (2005). Weapon violence in adolescence: Parent and school connectedness as protective factors. Journal of Adolescent Health, 37(4), 306-312.

Hirschfield, P. J. (2008). Preparing for prison: The criminalisation of school discipline in the USA. Theoretical Criminology, 12(1), 79-101.

Hughes, J. N. (2011). Longitudinal effects of teacher and student perceptions of teacher-student relationship qualities on academic adjustment. The Elementary School Journal, 112(1), 38-60.

Huppert, F. A. (2012). Forward. In S. Roffey (Ed.), Positive relationships: Evidence base practice around the world (pp. vii-ix). Springer Social Sciences.

Hurtado, S., \& Carter, D. F. (1997). Effects of college transition and perceptions of the campus racial climate on Latino college students' sense of belonging. Sociology of Education, 70(4), 324-345.

Johnson, L. S. (2009). School contexts and student belonging: A mixed methods study of an innovative high school. The School Community Journal, 19(1), 99119.

Jose, P. E., Ryan, N., \& Pryor, J. (2012). Does social connectedness promote a greater sense of well-being in adolescence over time? Journal of Research on Adolescence, 22(2), 235-251. https://doi.org/10.1111/j.1532-7795.2012.007 83.x.

Karcher, M. J., \& Lee, Y. (2002). Connectedness among Taiwanese middle school students: A validation study of the Hemingway Measure of Adolescent Connectedness. Asia Pacific Education Review, 3(1), 92-114.

Klem, A. M., \& Connell, J. P. (2004). Relationships matter: Linking teacher support to student engagement and achievement. Journal of School Health, 74(7), 262273.

Knifsend, C., \& Graham, S. (2012). Too much of a good thing? How breadth of extracurricular participation relates to school-related affect and academic outcomes during adolescence. Journal of Youth and Adolescence, 41, 379-389. https://doi.org/10.1007/s10964-011-9737-4.

Korpershoek, H., Harms, T., de Boer, H., van Kuijk, M., \& Doolaard, S. (2016). A meta-analysis of the effects of classroom management strategies and classroom 
management programs on students' academic, behavioral, emotional, and motivational outcomes. Review of Educational Research, 86 (3), 643-680. https://doi. org/10.3102/0034654315626799.

Libbey, H. P. (2004). Measuring student relationships to school: Attachment, bonding, connectedness, and engagement. Journal of School Health, 74(7), 275-283.

Lim, M., Allen, K. A., Craig, H., Smith, D., \& Furlong, M. (2021). Feeling lonely and a need to belong: What is shared and distinct? Australian Journal of Psychology. https://doi.org/10.1080/00049530.2021.1883411.

Lohmeier, J. H., \& Lee, S. W. (2011). A school connectedness scale for use with adolescents. Educational Research and Evaluation, 17(2), 85-95.

Longobardi, C., Prino, L. E., Marengo, D., \& Settanni, M. (2016). Student-teacher relationships as a protective factor for school adjustment during the transition from middle to high school. Frontiers in Psychology, 7, 1988. https://doi.org/10. 3389/fpsyg.2016.01988.

Ma, X. (2003). Sense of belonging to school: Can schools make a difference? Journal of Educational Research, 96(3), 340-349. https://doi.org/10.1080/002206703 09596617.

Meece, J. L. (2003). Applying learner-centered principles to middle school education. Theory into Practice, 42(2), 109-116.

Meece, J. L., Herman, P., \& McCombs, B. L. (2003). Relations of learner-centered teaching practices to adolescents' achievement goals. International Journal of Educational Research, 39(4-5), 457-475.

National Foundation for Educational Research [NFER]. (2019). Education Inspection Framework 2019 NFER Response: Teacher Voice Data. Retrieved from: https://www.nfer.ac.uk/media/3428/teacher_views_on_ofsted_proposed_ education_inspection_framework.pdf.

Nichols, S. L. (2006). Teachers' and students' beliefs about student belonging in one middle school. Elementary School Journal, $106(3), 255-271$.

Obsuth, I., Murray, A. L., Malti, T., Sulger, P., Ribeaud, D., \& Sulger, P. (2017). A non-bipartite propensity score analysis of the effects of teacher-student relationshipson adolescent problem and prosocial behavior. Journal of Youth and Adolescence, 46 (8), 1661-1687.

O'Brien, K. A., \& Bowles, T. V. (2013). The Importance of Belonging for Adolescents in Secondary School Settings. The European Journal of Social \& Behavioural Sciences, 5(2), 976-984.

O'Connell, B. H., O'Shea, D., \& Gallagher, S. (2016). Enhancing social relationships through positive psychology activities: A randomized control trial. The Journal of Positive Psychology, 11, 149-162.

O'Keeffe, P. (2013). A sense of belonging: Improving student retention. College Student Journal, 47(4), 605-613.

OECD. (2019). PISA 2018 Results (Volume III): What School Life Means for Students' Lives. Author. 
Osterman, K. F. (2000). Students' need for belonging in the school community. Review of Educational Research, 70(3), 323-367.

Patterson Silver Wolf, D. A., Taylor, F., Maguin, E., \& Asher BlackDeer, A. (2019). You are college material-You belong: An underrepresented minority student retention intervention without deception. Journal of College Student Retention: Research, Theory \& Practice, 1521025119848749.

Pedlar, M. (2018). Teachers play a key role in helping students feel they 'belong' at school. The Conversation. https://theconversation.com/teachers-play-a-key-rolein-helping-students-feel-they-belong-at-school-99641.

Peterson, C. (2006). A primer in positive psychology. Oxford University Press.

Pittman, L. D., \& Richmond, A. (2007). Academic and psychological functioning in late adolescence: The importance of school belonging. The Journal of Experimental Education, 75(4), 270-290.

Quinn, S., \& Oldmeadow, J. A. (2013). Is the igeneration a 'we' generation? Social networking use among 9- to 13-year-olds and belonging. British Journal of Developmental Psychology, 31(1), 136-142.

Roffey, S. (2007). Transformation and emotional literacy: The role of school leaders in developing a caring community. Leading and Managing, 13(1), 16-30.

Roffey, S. (2012). Positive relationships: Evidence base practice around the world. Springer Social Sciences.

Rowe, F., \& Stewart, D. (2009). Promoting connectedness through whole-school approaches: A qualitative study. Health Education, 109(5), 396-413.

Ryan, R. M., \& Deci, E. L. (2000). Self-determination theory and the facilitation of intrinsic motivation, social development, and wellbeing. American Psychologist, 55, 68-78.

Sargeant, J. (2016). Are we expelling too many students from Australian schools? The Conversation. https://theconversation.com/are-we-expelling-toomany-children-from-australian-schools-65162.

Scott, G. (2003). Learning Principals: Leadership Capability and Learning Research. New South Wales Department of Education and Training, Professional Support and Curriculum Directorate.

Shochet, I. M., Dadds, M. R., Ham, D., \& Montague, R. (2006). School connectedness is an underemphasized parameter in adolescent mental health: Results of a community prediction study. Journal of Clinical Child \& Adolescent Psychology, 35(2), 170-179.

Shochet, I. M., Smyth, T. L., \& Homel, R. (2007). The impact of parental attachment on adolescent perception of the school environment and school connectedness. Australian and New Zealand Journal of Family Therapy, 28(2), $109-118$.

Simons-Morton, B. G., Crump, A. D., Haynie, D. L., \& Saylor, K. E. (1999). Student-school bonding and adolescent problem behavior. Health Education Research, 14(1), 99-107. 
Skinner, E. A., Zimmer-Gembeck, M. J., Connell, J. P., Eccles, J. S., \& Wellborn, J. G. (1998). Individual differences and the development of perceived control. Monographs of the Society for Research in Child Development, i-231.

Slaten, C. D., Ferguson, J. K., Allen, K. A., Brodrick, D.-V., \& Waters, L. (2016). School belonging: A review of the history, current trends, and future directions. The Educational and Developmental Psychologist, 33(1), 1-15. https://doi.org/10. 1017/edp.2016.6.

Slaten, C. D., Rose, C. A., Bonifay, W., \& Ferguson, J. (2018). Milwaukee youth belongingness scale: item response theory analysis. School Psychology Quarterly. Advanced online publication. https://doi.org/10.1037/spq0000299.

Stevens, T., Hamman, D., \& Olivárez, A., Jr. (2007). Hispanic students' perception of white teachers' mastery goal orientation influences sense of school belonging. Journal of Latinos and Education, 6(1), 55-70. https://doi.org/10.1080/153484 30709336677.

Strayhorn, T. L. (2018). College students' sense of belonging: A key to educational success for all students. Routledge.

Thompson, B., Diamond, K. E., McWilliam, R., Snyder, P., \& Snyder, S. W. (2005). Evaluating the quality of evidence from correlational research for evidence-based practice. Exceptional Children, 71(2), 181-194.

Tillery, A. D., Varjas, K., Roach, A. T., Kuperminc, G. P., \& Meyers, J. (2013). The importance of adult connections in adolescents' sense of school belonging: Implications for schools and practitioners. Journal of School Violence, 12(2), 134155. https://doi.org/10.1080/15388220.2012.762518.

Tinto, V. (1987). Leaving college: Rethinking the causes and cures of student attrition. University of Chicago Press.

Uslu, F., \& Gizir, S. (2017). School belonging of adolescents: The role of teacherstudent relationships, peer relationships and family involvement. Educational Sciences: Theory and Practice, 17(1), 63-82.

Uwah, C. J., McMahon, H. G., \& Furlow, C. F. (2008). School belonging, educational aspirations, and academic self-efficacy among African American male high school students: Implications for school counselors. Professional School Counseling, 11(5), 296-305.

Van Ryzin, M. J., Gravely, A. A., \& Roseth, C. J. (2009). Autonomy, belongingness, and engagement in school as contributors to adolescent psychological well-being. Journal of Youth and Adolescence, 38(1), 1-12.

Vidourek, R. A., \& King, K. A. (2014). Enhancing School Connectedness: Teachers' Perceived Confidence in Positively Connecting Students to School. International Journal of School \& Educational Psychology, 2(2), 85-94. https://doi.org/10.1080/ 21683603.2013.876949.

Wallace, T. L., Ye, F., \& Chhuon, V. (2012). Subdimensions of adolescent belonging in high school. Applied Developmental Science, 16(3), 122-139.

Walton, G. M., \& Cohen, G. L. (2007). A question of belonging: Race, social fit, and achievement. Journal of Personality and Social Psychology, 92, 82-96. 
Walton, G. M., \& Cohen, G. L. (2011). A brief social belonging intervention improves academic and health outcomes of minority students. Science, 331, 1447-1451.

Wang, M. T., \& Eccles, J. S. (2012). Social support matters: Longitudinal effects of social support on three dimensions of school engagement from middle to high school. Child Development, 83(3), 877-895.

Warren, M. A., \& Donaldson, S. I. (2018). Toward a positive psychology of relationships: New directions in theory and research. Westport, Connecticut: Praeger.

Wingspread Declaration on School Connections. (2004). Journal of School Health, $74(7), 233-234$.

Wong, T. K. Y., Parent, A.-M., \& Konishi, C. (2019). Feeling connected: The roles of student-teacher relationships and sense of school belonging on future orientation. International Journal of Educational Research, 94, 150-157. https://doi.org/ 10.1016/j.ijer.2019.01.008.

You, S., Ritchey, K. M., Furlong, M. J., Shochet, I., \& Boman, P. (2011). Examination of the latent structure of the psychological sense of school membership scale. Journal of Psychoeducational Assessment, 29(3), 225-237.

Zimmer-, M., Chipuer, H., Hanisch, M., Creed, P., \& McGregor, L. (2006). Relationships at school and stage-environment fit as resources for adolescent engagement and achievement. Journal of Adolescence, 29, 911-933.

Open Access This chapter is licensed under the terms of the Creative Commons Attribution 4.0 International License (http://creativecommons.org/licenses/by/4.0/), which permits use, sharing, adaptation, distribution and reproduction in any medium or format, as long as you give appropriate credit to the original author(s) and the source, provide a link to the Creative Commons license and indicate if changes were made.

The images or other third party material in this chapter are included in the chapter's Creative Commons license, unless indicated otherwise in a credit line to the material. If material is not included in the chapter's Creative Commons license and your intended use is not permitted by statutory regulation or exceeds the permitted use, you will need to obtain permission directly from the copyright holder.

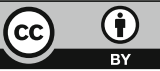

